\title{
Effect of Some Bio-Stimulants and Packaging Material on Quality Attributes of Snap Beans during Storage and Shelf Life Conditions
}

\author{
Shehata, S.A. ${ }^{1}$; Abd El-Rahman, S.Z. ${ }^{2}$; Emam, M.S. ${ }^{2}$; El-Helaly, M.A. ${ }^{1}$ and Gad El-Rab, N.A. ${ }^{2}$ \\ ${ }^{1}$ Vegetable Corps Department, Faculty of Agriculture, Cairo University, Giza, Egypt. \\ 2 Postharvest and Handling of Vegetable Crops Research Department, Horticulture Research Institute, \\ Agricultural Research Center, Giza, Egypt. \\ Correspondence author: Said_Shehata2@yahoo.com
}

\begin{abstract}
Two plastic house experiments were carried out during winter seasons of 2014/2015 and 2015/2016 in a clay loam soil at the Agricultural Experiment Station, Faculty of Agriculture, Cairo University and Laboratory of Handling of Vegetable Crops Department, Horticulture Research Institute, Giza, to study the effect of some bio-stimulants, viz., seaweed extract (SWE) at $0.2 \%$ as foliar spray, humic acid (HA) at $0.2 \%$ and effective microorganisms (EM) at $0.2 \%$ as soil application alone or in combinations and packaging of pods in microperforated polypropylene bags (micro- $\mathrm{PPPb}$, export package) or non-perforated polypropylene bags (non- $\mathrm{PPPb}$ ) on quality attributes and storability of snap beans (Phaseolus vulgaris L.) cv. Hama during storage at $5^{\circ} \mathrm{C}$ and shelf life at $10^{\circ} \mathrm{C}$. Results indicated that snap bean plants treated with the mixture of SWE+HA+EM and then packed in non- $\mathrm{PPPb}$ was the most effective treatment for improving storability and maintaining pod quality attributes, which gave the lowest values of weight loss $\%$ and fiber $\%$, maintained total carbohydrate $\%$ and protein $\%$, and gave good appearance of pods after 16 days of storage at $5^{\circ} \mathrm{C}+2$ days at $10^{\circ} \mathrm{C}$ (shelf life).
\end{abstract}

Keywords: Snap bean, bio-stimulants, seaweed extract, humic acid, effective microorganism, packaging, perforated bags, non-perforated bags, quality, storability.

\section{Introduction}

Snap bean (Phaseolus vulgaris L.) is one of the most important members of leguminous crops grown in Egypt for either local consumption or exportation. It is rich in protein, dietary fibers, minerals $(\mathrm{Ca}, \mathrm{P}$, $\mathrm{Fe}, \mathrm{K}, \mathrm{Mg}$ and $\mathrm{Mn}$ ) and vitamins (A, B1, B2 and C) with high amino acids (Kerlous, 1997). Pre-harvest plant nutrition is a major factor influencing fruit and vegetable quality (Sams, 1999). Increasing the productivity of snap bean pods with high quality and good storability is considered an important aim that could be achieved through using some biostimulants, viz., seaweed extract (Abou El-Yazied et al., 2012), humic acid (Gad El-Hak et al., 2012) and effective microorganisms (El-Sayed et al., 2015).

Seaweed extracts (SWE) are a known source of plant growth regulators such as cytokinins, auxins and auxin-like compounds, organic matter and fertilizer nutrients, amino acids and vitamins, complex polysaccharides, betaines and betaine-like compounds, sterols and growth inhibitor abscisic acid (Khan et al., 2009) which play important roles in metabolism and productivity of plants (Crouch and Van-Staden, 1993). Moreover, they are effective in improving quality of products and increasing postharvest shelf life (Abou El-Yazied et al., 2012). Mohamed (2014) showed that seaweed application on pea plants gave lower weight loss percentage, higher score of general appearance and maintaining total carbohydrate $\%$ and protein $\%$ in pods and gave the minimum values of fiber percentage in comparison to control treatment.
Humic acid (HA) is one of the major components of humus. Humates are natural organic substances, high in HA and containing most of the known trace minerals necessary to the development of plant life (Senn, 1991). Humic acid is produced by the chemical and biological decomposition of organic material with the help of micronutrients. It enhances soil fertility and improves physical, chemical and biological properties of soils (Mikkelsen, 2005), and increases the availability of nutrient elements and consequently affected plant growth, yield and quality (Gad El-Hak et al., 2012). Snap bean pods obtained from plants treated with humic acid had significantly surpassed those pods obtained from untreated plants (control) in minimizing pod weight loss $\%$, and gave higher score of general appearance and maintaining total carbohydrate $\%$ and protein $\%$ in pods and gave the minimum values of fiber percentage in pod during storage (El-Sayed et al., 2015).

Effective microorganisms (EM) are a commercial bio-fertilizer that contains a mixture of co-existing beneficial microorganisms collected from natural environments that are used as a soil amendment (Woodward, 2003). Snap bean pods obtained from plants treated with EM gave lower weight loss percentage, higher score of general appearance and maintaining protein $\%$ and total carbohydrate $\%$ of pods during storage (El-Sayed et al., 2015).

The use of selective plastic film for prolonging the storability of fruits was studied by many investigators, where the selection of proper 
packaging material is of crucial importance to create conditions able to guarantee the maintenance of product quality (Lucera et al., 2011). Shehata et al. (2015) found that snap bean pods packed in nonperforated polypropylene bags reduced weight loss, maintained overall quality and gave the highest score of general appearance during storage.

Therefore, the aim of this work was to study the effect of some bio-stimulants, viz., seaweed extract, humic acid and effective microorganisms alone or in combinations and packaging of pods in microperforated or non-perforated polypropylene bags on quality attributes and storability of snap beans during storage at $5^{\circ} \mathrm{C}$ and shelf life at $10^{\circ} \mathrm{C}$.

\section{Materials and Methods}

This experiment was carried out under plastic house conditions during the winter seasons of 2014/2015 and 2015/2016 at the Agricultural Experiment Station, Faculty of Agriculture, Cairo University. Seeds of snap bean cv. Hama were sown on $15^{\text {th }}$ and $21^{\text {th }}$ October in 2014 and 2015 seasons, respectively. The plastic house was $40 \mathrm{~m}$ long and 8 $\mathrm{m}$ wide $\left(320 \mathrm{~m}^{2}\right)$ and divided into five beds, each $1 \mathrm{~m}$ wide and $40 \mathrm{~m}$ long. The experiment occupied three beds. Seeds were sown on $50 \mathrm{~cm}$ apart on two sides of each bed; the area of each experimental unit was 5 $\mathrm{m}^{2}$ with 20 plants.

\section{This experiment included eight treatments as} follow:

1. Untreated plants (control).

2. Seaweed extract (SEW) at $0.2 \%$ as foliar spray.

3. Humic acid (HA) at $0.2 \%$ as soil application.

4. Effective microorganisms (EM) at $0.2 \%$ as soil application.

5. Seaweed extract + Humic acid (SWE at $0.2 \%+$ $\mathrm{HA}$ at $0.2 \%$ ).

6. Seaweed extract + Effective microorganisms (SWE at $0.2 \%+\mathrm{EM}$ at $0.2 \%$ ).

7. Humic acid + Effective microorganisms (HA at $0.2 \%+\mathrm{EM}$ at $0.2 \%$ ).

8. Seaweed extract + Humic acid + Effective microorganisms (SWE at $0.2 \%+\mathrm{HA}$ at $0.2 \%+$ EM at $0.2 \%$ )

The previous treatments were arranged in a complete randomized block design with three replicates. These treatments were applied three times during the growing period of snap bean plants at 30 , 45 and 60 days after sowing and the fertilizers were manually added separately for each plant. The recommended agricultural practices for commercial snap bean production, i.e., drip irrigation; fertilization and weed control were followed according to the Egyptian Ministry of Agriculture recommendations.

Pods obtained from the previous treatments were harvested at the suitable maturity stage of marketing on $11^{\text {th }}$ and $14^{\text {th }}$ of January in the first and second seasons, respectively; then delivered to the laboratory of Handling of Vegetable Crops Department, Horticulture Research Center, Giza. Pods uniform in length, diameter and color and free from blemishes were selected for storage experiment. These pods were packed in micro-perforated polypropylene bags (which are used for exporting the Egyptian green beans (micro-PPPb)) or nonperforated polypropylene bags (non-PPPb); $(30 \mu \mathrm{m}$ thickness, $15 \times 25 \mathrm{~cm}$ size), and each bag had $200 \mathrm{~g}$ as one replicate. Fifteen replicates from microperforated or non-perforated bags were prepared for each pre-harvest treatment. All treatments were stored at $5^{\circ} \mathrm{C}$ and $90-95 \%$ relative humidity for 16 days plus 2 days at $10^{\circ} \mathrm{C}$ (shelf life). The experimental design was completely randomized design with three replicates. Three replicates from each treatment were taken at random and examined immediately after harvest and after 4, 8, 12 and 16 days at $5^{\circ} \mathrm{C}$ plus 2 days at $10^{\circ} \mathrm{C}$ (shelf life) for the following properties:

1. Weight loss percentage as estimated according to the following equation:

$$
\begin{aligned}
& \text { Weight Initial weight of pods - weight } \times \\
& \operatorname{loss} \%=\frac{\text { of pods at sampling date }}{\text { Initial weight loss }} 100
\end{aligned}
$$

2. General appearance as evaluated using a scale from 9 to 1 , where $9=$ excellent, $7=\operatorname{good}, 5=$ fair, $3=$ poor, $1=$ unsalable; pods rating (5) or below were considered as unmarketable, as described by Kader et al. (1973). It was recorded for both of the shriveling, wilting, color change and decay or any their visible deterioration.

3. Total carbohydrates percentage in dry matter of pods: It was measured according to Dubois et al. (1956).

4. Protein percentage in dry matter of pods: it was calculated by multiplying the total nitrogen by the factor 6.25 , it was determined according to AOAC (1990).

5. Fiber percentage in dry matter of pods: it was determined according to Rai and Mudgal (1988).

The last three properties were examined immediately after harvest and after 8 and 16 days at $5^{\circ} \mathrm{C}$ plus 2 days at $10^{\circ} \mathrm{C}$ (shelf life).

All data were subjected to statistical analysis according to the method described by Snedecor and Cochran (1980).

\section{Results and Discussion}

\section{Weight loss percentage}

Data in Tables $1 \& 2$ reveal that weight loss percentage of snap bean pods was increased considerably and consistently with the prolongation of storage period in the two seasons. These results are in agreement with those obtained by El-Sayed et al. (2015) and Shehata et al. (2015) on snap beans. The 
loss in weight may be attributed to transpiration, respiration and other senescence related metabolic processes during storage (Wills et al., 1989).

All pre-harvest treatments gave significantly lower weight loss percentage of pods as compared to untreated plants (control); however, snap bean pods obtained from plants treated with the mixture of $\mathrm{SWE}+\mathrm{HA}+\mathrm{EM}$ or HA + EM surpassed those pods obtained from other treatments or untreated control in minimizing pod weight loss percentage during storage and shelf life with significant differences between them in the two seasons. On the contrary, pods obtained from untreated plants gave the highest values of weight loss percentage. These results were achieved in the two seasons and are in agreement with those obtained by Mohamed (2014) for SWE and HA on pea. Such results may be due to the beneficial effect of SWE, HA and EM on vegetative growth and chemical composition of snap beans which in turn maintained the metabolic homeostasis after harvest and reduced dehydration of pods.

Concerning the effect of packaging material, data reveal that pods packed in non- $\mathrm{PPPb}$ reduced the weight loss percentage as compared to those packed in micro-PPPb during storage and shelf life with significant differences between them in the two seasons. These results are in agreement with those obtained by Shehata et al. (2015) on snap beans. Packaging in non-perforated bags creates a modified atmosphere with higher concentration of $\mathrm{CO}_{2}$ and reduced $\mathrm{O}_{2}$ around the product which slows down the metabolic processes and transpiration (Thompson, 1996), which diminished the weight loss during storage (Wang and Qi, 1997).

Table 1. Effect of some bio-stimulants and packaging material on weight loss (\%) of snap beans during storage at $5^{\circ} \mathrm{C}$, with additional 2 days at $10^{\circ} \mathrm{C}$ in $2014 / 2015$ season.

\begin{tabular}{|c|c|c|c|c|c|c|c|}
\hline \multirow{2}{*}{ Treatment $^{x}$} & \multirow{2}{*}{ Packaging $^{\mathrm{y}}$} & \multicolumn{6}{|c|}{ Storage period (day) } \\
\hline & & $0+2$ & $4+2$ & $8+2$ & $12+2$ & $16+2$ & Mean \\
\hline \multirow{3}{*}{ Control } & Micro-PPPb & 3.58 & 5.50 & 7.60 & 8.30 & 9.90 & 6.98 \\
\hline & Non-PPPb & 0.95 & 1.24 & 1.38 & 1.62 & 2.08 & 1.45 \\
\hline & Mean & 2.27 & 3.37 & 4.49 & 4.96 & 5.99 & 4.22 \\
\hline \multirow{3}{*}{ SWE } & Micro-PPPb & 2.82 & 4.71 & 7.20 & 8.00 & 9.16 & 6.38 \\
\hline & Non-PPPb & 0.84 & 1.07 & 1.26 & 1.49 & 1.93 & 1.32 \\
\hline & Mean & 1.83 & 2.89 & 4.23 & 4.75 & 5.55 & 3.85 \\
\hline \multirow{3}{*}{ HA } & Micro-PPPb & 2.00 & 4.20 & 6.10 & 7.00 & 7.90 & 5.44 \\
\hline & Non-PPPb & 0.55 & 0.83 & 1.11 & 1.39 & 1.82 & 1.14 \\
\hline & Mean & 1.28 & 2.52 & 3.61 & 4.20 & 4.86 & 3.29 \\
\hline \multirow{3}{*}{ EM } & Micro-PPPb & 2.20 & 4.30 & 6.20 & 7.20 & 8.55 & 5.69 \\
\hline & Non-PPPb & 0.60 & 0.92 & 1.20 & 1.40 & 1.87 & 1.20 \\
\hline & Mean & 1.40 & 2.61 & 3.70 & 4.30 & 5.21 & 3.44 \\
\hline \multirow{3}{*}{ SWE+HA } & Micro-PPPb & 1.87 & 3.82 & 5.60 & 6.47 & 7.70 & 5.09 \\
\hline & Non-PPPb & 0.49 & 0.73 & 0.93 & 1.20 & 1.62 & 0.99 \\
\hline & Mean & 1.18 & 2.28 & 3.27 & 3.84 & 4.66 & 3.04 \\
\hline \multirow{3}{*}{ SWE+EM } & Micro-PPPb & 2.01 & 4.00 & 6.00 & 7.00 & 8.11 & 5.42 \\
\hline & Non-PPPb & 0.52 & 0.87 & 1.10 & 1.30 & 1.74 & 1.11 \\
\hline & Mean & 1.27 & 2.44 & 3.55 & 4.15 & 4.93 & 3.27 \\
\hline \multirow{3}{*}{ HA+EM } & Micro-PPPb & 1.53 & 3.41 & 5.10 & 6.00 & 6.40 & 4.49 \\
\hline & Non-PPPb & 0.42 & 0.80 & 0.98 & 1.30 & 1.41 & 0.98 \\
\hline & Mean & 0.98 & 2.11 & 3.04 & 3.65 & 3.91 & 2.74 \\
\hline \multirow{3}{*}{ SWE+HA+EM } & Micro-PPPb & 1.23 & 2.78 & 4.30 & 5.00 & 5.60 & 3.78 \\
\hline & Non-PPPb & 0.20 & 0.30 & 0.60 & 0.85 & 1.30 & 0.65 \\
\hline & Mean & 0.72 & 1.54 & 2.45 & 2.93 & 3.45 & 2.22 \\
\hline \multirow{2}{*}{ Mean } & Micro-PPPb & 2.16 & 4.09 & 6.01 & 6.87 & 7.92 & 5.41 \\
\hline & Non-PPPb & 0.57 & 0.85 & 1.07 & 1.32 & 1.72 & 1.11 \\
\hline Mean & & 1.36 & 2.47 & 3.54 & 4.10 & 4.82 & \\
\hline \multicolumn{8}{|l|}{ LSD at $5 \%$} \\
\hline & Treatment $(\mathbf{T})$ & & & $\mathbf{T} \times \mathbf{P}$ & & & \\
\hline & Packaging (P) & & & $\mathbf{T} \times \mathbf{S}$ & & & \\
\hline & Storage period $(S)$ & & & $\mathbf{P} \times \mathbf{S}$ & & & \\
\hline & & & & $\mathbf{T} \times \mathbf{P} \times \mathbf{S}$ & & & \\
\hline
\end{tabular}

${ }^{x}$ SWE: Seaweed extract, HA: Humic acid, EM: Effective microorganisms.

y Micro-PPPb: Micro-perforated polypropylene bags.

Non-PPPb: Non-perforated polypropylene bags. 
Table 2. Effect of some bio-stimulants and packaging material on weight loss (\%) of snap beans during storage at $5^{\circ} \mathrm{C}$, with additional 2 days at $10^{\circ} \mathrm{C}$ in $2015 / 2016$ season.

\begin{tabular}{|c|c|c|c|c|c|c|c|}
\hline \multirow{2}{*}{ Treatment $^{x}$} & \multirow{2}{*}{ Packaging $^{\mathrm{y}}$} & \multicolumn{6}{|c|}{ Storage period (day) } \\
\hline & & $0+2$ & $4+2$ & $8+2$ & $12+2$ & $16+2$ & Mean \\
\hline \multirow{3}{*}{ Control } & Micro-PPPb & 3.85 & 5.75 & 7.74 & 8.85 & 10.41 & 7.32 \\
\hline & Non-PPPb & 1.03 & 1.21 & 1.40 & 1.67 & 2.40 & 1.54 \\
\hline & Mean & 2.44 & 3.48 & 4.57 & 5.26 & 6.41 & 4.43 \\
\hline \multirow{3}{*}{ SWE } & Micro-PPPb & 3.13 & 4.96 & 7.27 & 8.41 & 9.46 & 6.65 \\
\hline & Non-PPPb & 0.92 & 1.10 & 1.29 & 1.50 & 1.88 & 1.34 \\
\hline & Mean & 2.03 & 3.03 & 4.28 & 4.96 & 5.67 & 3.99 \\
\hline \multirow{3}{*}{ HA } & Micro-PPPb & 2.35 & 4.50 & 6.41 & 7.38 & 8.42 & 5.81 \\
\hline & Non-PPPb & 0.59 & 0.82 & 1.09 & 1.37 & 1.72 & 1.12 \\
\hline & Mean & 1.47 & 2.66 & 3.75 & 4.38 & 5.07 & 3.46 \\
\hline \multirow{3}{*}{ EM } & Micro-PPPb & 2.60 & 4.66 & 6.52 & 7.58 & 8.94 & 6.06 \\
\hline & Non-PPPb & 0.68 & 0.91 & 1.20 & 1.48 & 1.80 & 1.21 \\
\hline & Mean & 1.64 & 2.79 & 3.86 & 4.53 & 5.37 & 3.64 \\
\hline \multirow{3}{*}{ SWE+HA } & Micro-PPPb & 2.22 & 4.12 & 5.96 & 6.60 & 8.07 & 5.40 \\
\hline & Non-PPPb & 0.52 & 0.72 & 0.91 & 1.19 & 1.50 & 0.97 \\
\hline & Mean & 1.37 & 2.42 & 3.44 & 3.89 & 4.78 & 3.18 \\
\hline \multirow{3}{*}{ SWE+EM } & Micro-PPPb & 2.34 & 4.37 & 6.34 & 7.38 & 8.55 & 5.80 \\
\hline & Non-PPPb & 0.56 & 0.80 & 1.05 & 1.30 & 1.76 & 1.09 \\
\hline & Mean & 1.45 & 2.59 & 3.70 & 4.34 & 5.16 & 3.44 \\
\hline \multirow{3}{*}{ HA+EM } & Micro-PPPb & 1.83 & 3.76 & 5.43 & 6.37 & 6.75 & 4.83 \\
\hline & Non-PPPb & 0.47 & 0.68 & 0.89 & 1.19 & 1.48 & 0.94 \\
\hline & Mean & 1.15 & 2.22 & 3.16 & 3.78 & 4.12 & 2.89 \\
\hline \multirow{3}{*}{ SWE+HA+EM } & Micro-PPPb & 1.30 & 2.90 & 4.00 & 5.20 & 6.31 & 3.94 \\
\hline & Non-PPPb & 0.15 & 0.30 & 0.52 & 0.74 & 1.15 & 0.57 \\
\hline & Mean & 0.73 & 1.60 & 2.26 & 2.97 & 3.73 & 2.26 \\
\hline \multirow{2}{*}{ Mean } & Micro-PPPb & 2.45 & 4.38 & 6.21 & 7.22 & 8.36 & 5.73 \\
\hline & Non-PPPb & 0.61 & 0.82 & 1.04 & 1.30 & 1.71 & 1.10 \\
\hline Mean & & 1.53 & 2.60 & 3.63 & 4.26 & 5.04 & \\
\hline \multicolumn{8}{|l|}{ LSD at $5 \%$} \\
\hline & Treatment $(T)$ & \multicolumn{2}{|c|}{0.28} & $\mathbf{T} \times \mathbf{P}$ & \multicolumn{2}{|c|}{0.39} & \\
\hline & Packaging (P) & \multicolumn{2}{|c|}{0.14} & $\mathbf{T} \times \mathbf{S}$ & \multicolumn{2}{|c|}{0.62} & \\
\hline & Storage period $(S)$ & \multicolumn{2}{|c|}{0.22} & $\mathbf{P} \times \mathbf{S}$ & \multicolumn{2}{|c|}{0.31} & \\
\hline & & & & $\mathbf{T} \times \mathbf{P} \times \mathbf{S}$ & & & \\
\hline
\end{tabular}

x SWE: Seaweed extract, HA: Humic acid, EM: Effective microorganisms.

y Micro-PPPb: Micro-perforated polypropylene bags.

Non-PPPb: Non-perforated polypropylene bags.

The interaction between pre-harvest treatments and packaging material had significant effect on weight loss percentage during storage and shelf life in the two seasons. Snap bean pods obtained from plants treated with the mixture of SWE + HA + EM and then packed in non- $\mathrm{PPPb}$ had significantly the lowest value of weight loss $\%$, while pods obtained from untreated plants and then packed in micro- $\mathrm{PPPb}$ had the highest value of weight loss during storage and shelf life in the two seasons.

In general, the interaction among pre-harvest treatments, packaging material and storage periods plus shelf life was significant in both seasons. After 16 days at $5^{\circ} \mathrm{C}+2$ days at $10^{\circ} \mathrm{C}$, snap bean pods obtained from plants treated with the mixture of $\mathrm{SWE}+\mathrm{HA}+\mathrm{EM}$ or HA + EM and then packed in non-PPPb showed the lowest weight loss percentage without significant differences between them, while those obtained from untreated plants or SWE treatment and then packed in micro- $\mathrm{PPPb}$ gave the highest values of weight loss percentage without significant differences between them in the first season.

\section{General appearance}

Data in Tables $3 \& 4$ reveal that there was significant reduction in general appearance (GA) of snap bean pods with the prolongation of storage period and shelf life in both seasons. Similar results were reported by Shehata et al. (2015) on snap bean pods. The decreases in GA of snap bean pods during storage period might be due to shriveling, wilting, color change and decay (El-Mogy, 2001).

All pre-harvest treatments had the higher score of general appearance when compared with the untreated plants (control) during storage and shelf life. However snap bean pods obtained from plants treated with the mixture of SWE + HA + EM gave the highest score of GA of pods, followed by HA + EM treatment with significant differences between 
them in the two seasons. The worst GA was recorded for the untreated control. These results were achieved in the two seasons and are in agreement with those obtained by Mohamed (2014) for SWE and HA on pea. The enhancement effect in both seasons might be attributed to that SWE, HA and EM materials contains nutrient elements and organic compounds (Khan et al., 2009) and rich in both organic and mineral substances (Gad El-Hak et al., 2012), these minerals (potassium, calcium, iron, manganese and magnesium) reducing weight loss percentage and maintaining green color during storage (Shehata et al., 2015).

Concerning the effect of packaging material, data reveal that pods packed in non-PPPb showed the highest intensities of freshness, greenness, and snappiness, while those packed in micro- $\mathrm{PPPb}$ showed the lowest intensities of these attributes. These results were achieved in the two seasons and are in agreement with those obtained by Shehata $e t$ al. (2015) on snap beans. Snap bean pods packed in sealed bags made a significant contribution to extending the postharvest longevity of pods having a low rate of postharvest water loss (Youssef et al., 2010); water saturated atmosphere within the packages controlled water loss, hence maintaining the pod quality in term of freshness and absence of defects and rotting thereby extended postharvest longevity of snap bean pods (Fallik et al., 2002).

The interaction between pre-harvest treatments and packaging material was significant in the two seasons; however, snap bean pods obtained from plants treated with the mixture of SWE + HA + $\mathrm{EM}$ and then packed in non-PPPb had significantly the highest score of GA, followed by HA + EM and $\mathrm{SWE}+\mathrm{HA}$ and then packed in non-PPPb during storage and shelf life without significant differences between them in the two seasons.

Table 3. Effect of some bio-stimulants and packaging material on general appearance (score) of snap beans during storage at $5^{\circ} \mathrm{C}$, with additional 2 days at $10^{\circ} \mathrm{C}$ in $2014 / 2015$ season. ${ }^{x}$

\begin{tabular}{|c|c|c|c|c|c|c|c|}
\hline \multirow{2}{*}{ Treatment $^{\mathbf{y}}$} & \multirow{2}{*}{ Packaging $^{\mathrm{z}}$} & \multicolumn{6}{|c|}{ Storage period (day) } \\
\hline & & $0+2$ & $4+2$ & $8+2$ & $12+2$ & $16+2$ & Mean \\
\hline \multirow{3}{*}{ Control } & Micro-PPPb & 9.00 & 7.67 & 5.67 & 3.00 & 1.00 & 5.27 \\
\hline & Non-PPPb & 9.00 & 9.00 & 7.00 & 6.33 & 3.00 & 6.87 \\
\hline & Mean & 9.00 & 8.34 & 6.33 & 4.67 & 2.00 & 6.07 \\
\hline \multirow{3}{*}{ SWE } & Micro-PPPb & 9.00 & 8.33 & 5.67 & 5.00 & 3.00 & 6.20 \\
\hline & Non-PPPb & 9.00 & 9.00 & 7.67 & 6.33 & 4.33 & 7.27 \\
\hline & Mean & 9.00 & 8.67 & 6.67 & 5.67 & 3.67 & 6.73 \\
\hline \multirow{3}{*}{ HA } & Micro-PPPb & 9.00 & 9.00 & 7.00 & 5.67 & 5.00 & 7.13 \\
\hline & Non-PPPb & 9.00 & 9.00 & 8.33 & 7.00 & 5.67 & 7.80 \\
\hline & Mean & 9.00 & 9.00 & 7.67 & 6.33 & 5.34 & 7.47 \\
\hline \multirow{3}{*}{ EM } & Micro-PPPb & 9.00 & 8.33 & 6.33 & 5.00 & 4.33 & 6.60 \\
\hline & Non-PPPb & 9.00 & 9.00 & 7.67 & 7.00 & 5.00 & 7.53 \\
\hline & Mean & 9.00 & 8.67 & 7.00 & 6.00 & 4.67 & 7.07 \\
\hline \multirow{3}{*}{ SWE+HA } & Micro-PPPb & 9.00 & 9.00 & 7.67 & 6.33 & 5.67 & 7.53 \\
\hline & Non-PPPb & 9.00 & 9.00 & 8.33 & 7.00 & 6.33 & 7.93 \\
\hline & Mean & 9.00 & 9.00 & 8.00 & 6.67 & 6.00 & 7.73 \\
\hline \multirow{3}{*}{ SWE+EM } & Micro-PPPb & 9.00 & 8.33 & 7.00 & 5.67 & 5.00 & 7.00 \\
\hline & Non-PPPb & 9.00 & 9.00 & 7.67 & 7.00 & 6.33 & 7.80 \\
\hline & Mean & 9.00 & 8.67 & 7.34 & 6.33 & 5.67 & 7.40 \\
\hline \multirow{3}{*}{ HA+EM } & Micro-PPPb & 9.00 & 9.00 & 7.67 & 7.00 & 5.67 & 7.67 \\
\hline & Non-PPPb & 9.00 & 9.00 & 8.33 & 7.00 & 6.33 & 7.93 \\
\hline & Mean & 9.00 & 9.00 & 8.00 & 7.00 & 6.00 & 7.80 \\
\hline \multirow{3}{*}{ SWE+HA+EM } & Micro-PPPb & 9.00 & 9.00 & 8.33 & 7.00 & 6.33 & 7.93 \\
\hline & Non-PPPb & 9.00 & 9.00 & 9.00 & 8.33 & 7.67 & 8.60 \\
\hline & Mean & 9.00 & 9.00 & 8.67 & 7.67 & 7.00 & 8.27 \\
\hline \multirow{2}{*}{ Mean } & Micro-PPPb & 9.00 & 8.58 & 6.92 & 5.58 & 4.50 & 6.92 \\
\hline & Non-PPPb & 9.00 & 9.00 & 8.00 & 7.00 & 5.58 & 7.72 \\
\hline Mean & & 9.00 & 8.79 & 7.46 & 6.29 & 5.04 & \\
\hline \multicolumn{8}{|l|}{ LSD at $5 \%$} \\
\hline Treatment $(\mathbf{T})$ & & \multicolumn{2}{|c|}{0.37} & $\mathbf{T} \times \mathbf{P}$ & \multicolumn{2}{|c|}{0.53} & \\
\hline \multicolumn{2}{|l|}{ Packaging (P) } & \multicolumn{2}{|c|}{0.19} & $\mathbf{T} \times \mathbf{S}$ & \multicolumn{2}{|c|}{0.83} & \\
\hline \multirow[t]{2}{*}{ Storage period $(\mathbf{S})$} & & \multirow{2}{*}{\multicolumn{2}{|c|}{0.29}} & $\mathbf{P} \times \mathbf{S}$ & \multicolumn{2}{|c|}{0.42} & \\
\hline & & & & $\mathbf{T} \times \mathbf{P} \times \mathbf{S}$ & & & \\
\hline
\end{tabular}

$\bar{x}$ General appearance was measured on a scale from 9 to 1 where $9=$ excellent, $7=$ good, $5=$ fair, $3=$ poor, $1=$ unsalable. y SWE: Seaweed extract, HA: Humic acid, EM: Effective microorganisms.

${ }^{\mathrm{z}}$ Micro-PPPb: Micro-perforated polypropylene bags.

Non-PPPb: Non-perforated polypropylene bags. 
Table 4. Effect of some bio-stimulants and packaging material on general appearance (score) of snap beans during storage at $5^{\circ} \mathrm{C}$, with additional 2 days at $10^{\circ} \mathrm{C}$ in $2015 / 2016$ season. ${ }^{x}$

\begin{tabular}{|c|c|c|c|c|c|c|c|}
\hline \multirow{2}{*}{ Treatment $^{y}$} & \multirow{2}{*}{ Packaging $^{\mathrm{z}}$} & \multicolumn{6}{|c|}{ Storage period (day) } \\
\hline & & $0+2$ & $4+2$ & $8+2$ & $12+2$ & $16+2$ & Mean \\
\hline \multirow{3}{*}{ Control } & Micro-PPPb & 9.00 & 7.67 & 5.67 & 3.00 & 1.67 & 5.40 \\
\hline & Non-PPPb & 9.00 & 9.00 & 7.00 & 5.67 & 3.67 & 6.87 \\
\hline & Mean & 9.00 & 8.33 & 6.33 & 4.33 & 2.67 & 6.13 \\
\hline \multirow{3}{*}{ SWE } & Micro-PPPb & 9.00 & 8.33 & 5.67 & 5.00 & 3.67 & 6.33 \\
\hline & Non-PPPb & 9.00 & 9.00 & 7.67 & 6.33 & 4.33 & 7.27 \\
\hline & Mean & 9.00 & 8.67 & 6.67 & 5.67 & 4.00 & 6.80 \\
\hline \multirow{3}{*}{ HA } & Micro-PPPb & 9.00 & 9.00 & 7.00 & 5.67 & 5.00 & 7.13 \\
\hline & Non-PPPb & 9.00 & 9.00 & 8.33 & 7.00 & 5.67 & 7.80 \\
\hline & Mean & 9.00 & 9.00 & 7.67 & 6.33 & 5.33 & 7.47 \\
\hline \multirow{3}{*}{ EM } & Micro-PPPb & 9.00 & 8.33 & 6.33 & 5.00 & 4.33 & 6.60 \\
\hline & Non-PPPb & 9.00 & 9.00 & 7.67 & 7.00 & 5.00 & 7.53 \\
\hline & Mean & 9.00 & 8.67 & 7.00 & 6.00 & 4.67 & 7.07 \\
\hline \multirow{3}{*}{ SWE+HA } & Micro-PPPb & 9.00 & 9.00 & 7.67 & 6.33 & 5.67 & 7.53 \\
\hline & Non-PPPb & 9.00 & 9.00 & 8.33 & 7.00 & 6.33 & 7.93 \\
\hline & Mean & 9.00 & 9.00 & 8.00 & 6.67 & 6.00 & 7.73 \\
\hline \multirow{3}{*}{ SWE+EM } & Micro-PPPb & 9.00 & 9.00 & 7.00 & 5.67 & 5.00 & 7.13 \\
\hline & Non-PPPb & 9.00 & 9.00 & 7.67 & 7.00 & 6.33 & 7.80 \\
\hline & Mean & 9.00 & 9.00 & 7.33 & 6.33 & 5.67 & 7.47 \\
\hline \multirow{3}{*}{ HA+EM } & Micro-PPPb & 9.00 & 9.00 & 7.67 & 7.00 & 5.67 & 7.67 \\
\hline & Non-PPPb & 9.00 & 9.00 & 8.33 & 7.67 & 6.33 & 8.07 \\
\hline & Mean & 9.00 & 9.00 & 8.00 & 7.34 & 6.00 & 7.87 \\
\hline \multirow{3}{*}{ SWE+HA+EM } & Micro-PPPb & 9.00 & 9.00 & 7.67 & 7.00 & 6.33 & 7.80 \\
\hline & Non-PPPb & 9.00 & 9.00 & 9.00 & 9.00 & 7.67 & 8.73 \\
\hline & Mean & 9.00 & 9.00 & 8.34 & 8.00 & 7.00 & 8.27 \\
\hline \multirow{2}{*}{ Mean } & Micro-PPPb & 9.00 & 8.67 & 6.83 & 5.58 & 4.67 & 6.95 \\
\hline & Non-PPPb & 9.00 & 9.00 & 8.00 & 7.08 & 5.67 & 7.75 \\
\hline \multirow{5}{*}{$\begin{array}{l}\text { Mean } \\
\text { LSD at } 5 \%\end{array}$} & & 9.00 & 8.83 & 7.42 & 6.33 & 5.17 & \\
\hline & Treatment $(\mathbf{T})$ & & & $\mathbf{T} \times \mathbf{P}$ & 0.54 & & \\
\hline & Packaging (P) & & & $\mathbf{T} \times \mathbf{S}$ & 0.86 & & \\
\hline & Storage period (S) & & & $\mathbf{P} \times \mathbf{S}$ & 0.43 & & \\
\hline & & & & $\mathbf{T} \times \mathbf{P} \times \mathbf{S}$ & 1.21 & & \\
\hline
\end{tabular}

${ }^{x}$ General appearance was measured on a scale from 9 to 1 where $9=$ excellent, $7=$ good, $5=$ fair, $3=$ poor, $1=$ unsalable. y SWE: Seaweed extract, HA: Humic acid, EM: Effective microorganisms.

${ }^{z}$ Micro-PPPb: Micro-perforated polypropylene bags.

Non-PPPb: Non-perforated polypropylene bags.

Concerning the interaction among pre-harvest treatments, packaging material and storage periods plus shelf life, results reveal that snap bean pods obtained from plants treated with the mixture of $\mathrm{SWE}+\mathrm{HA}+\mathrm{EM}$ and then packed in non-PPPb did not exhibit any changes in their appearance till 12 days at $5^{\circ} \mathrm{C}+2$ days at $10^{\circ} \mathrm{C}$ and gave good appearance up to 16 days at $5^{\circ} \mathrm{C}+2$ days at $10^{\circ} \mathrm{C}$; while, pods packed in micro-PPPb rated good appearance after 12 days at $5^{\circ} \mathrm{C}+2$ days at $10^{\circ} \mathrm{C}$. Snap bean pods which obtained from untreated control and packed in micro-PPPb rated the unsalable appearance at the end of storage in the two seasons.

\section{Total carbohydrates percentage}

Data in Tables 5\&6 reveal that total carbohydrates $\%$ of snap bean pods decreased with the prolongation of storage period and shelf life, these results were achieved in the two seasons and are in agreement with those obtained by El-Sayed et al. (2015) on snap beans. The reduction in total carbohydrates during storage may be due to the higher rate of sugar loss through respiration than water loss through transpiration (Wills et al., 1998).

All pre-harvest treatments had significantly the highest value of total carbohydrates \% as compared with those obtained from untreated plants during storage and shelf life. Snap bean pods obtained from plants treated with the mixture of SWE + HA + EM or $\mathrm{HA}+\mathrm{EM}$ were the most effective treatments in maintaining total carbohydrates $\%$ with significant differences between them in the two seasons. On the other hand, the lowest value of total carbohydrates \% was recorded in pods of untreated plants. These results were achieved in the two seasons and are in agreement with those obtained by El-Sayed et al. (2015) on snap bean pods. The positive effect of SWE treatment on the percentage of carbohydrates 
may be due to its enhanced effect on leaf area (photosynthetic surfaces), content of chlorophylls and content of some important minerals as shown by Abou El-Yazied et al. (2012) on snap bean and then maintained carbohydrates content during storage (Mohamed, 2014). Also, HA application has been directly correlated with enhanced uptake of macronutrients, such as nitrogen, phosphorus and sulfur (Chen and Avied, 1990), increasing plant growth promoters (Kaya et al., 2005) in addition to increasing assimilate production which mean higher carbohydrates going to the pods and less stress on the growing pods (Tantawy et al., 2009) and also maintained carbohydrates during storage (El-Sayed et al., 2015). EM application increased leaf total chlorophyll content which reflected on improving vegetative growth which leads to more carbohydrates production through photosynthesis process (Higa, 1991) and also maintained carbohydrates content during storage (El-Sayed et al., 2015).
Concerning the effect of packaging material, data reveal that snap bean pods packed in non-PPPb had the highest value of total carbohydrates $\%$, while the lowest ones were recorded for pods packed in micro$\mathrm{PPPb}$. These results were achieved in the two seasons and are in agreement with those obtained by ElBassiouny (2003) on snap bean pods and these results might be due to the reduction of respiration rate and carbohydrate resource was consumed slightly during storage (Hammam, 2016).

The interaction between pre-harvest treatments and packaging material was significant in the two seasons. Snap bean pods obtained from plants treated with the mixture of SWE + HA + EM and then packed in non- $\mathrm{PPPb}$ or micro-PPPb had the highest values of total carbohydrates \% with significant differences between them in the second season. The lowest ones were found in those obtained from untreated plants and then packed in micro- $\mathrm{PPPb}$ or non- $\mathrm{PPPb}$ without significant differences between them in the two seasons.

Table 5. Effect of some bio-stimulants and packaging material on total carbohydrates (\%) of snap beans during storage at $5^{\circ} \mathrm{C}$, with additional 2 days at $10^{\circ} \mathrm{C}$ in $2014 / 2015$ season.

\begin{tabular}{|c|c|c|c|c|c|}
\hline \multirow{2}{*}{ Treatment $^{x}$} & \multirow{2}{*}{ Packaging ${ }^{\mathrm{y}}$} & \multicolumn{4}{|c|}{ Storage period (day) } \\
\hline & & $0+2$ & $8+2$ & $16+2$ & Mean \\
\hline \multirow{3}{*}{ Control } & Micro-PPPb & 21.94 & 18.62 & 15.10 & 18.55 \\
\hline & Non-PPPb & 22.16 & 19.04 & 16.52 & 19.24 \\
\hline & Mean & 22.05 & 18.83 & 15.81 & 18.90 \\
\hline \multirow{3}{*}{ SWE } & Micro-PPPb & 23.40 & 20.43 & 17.40 & 20.41 \\
\hline & Non-PPPb & 23.55 & 20.88 & 18.00 & 20.81 \\
\hline & Mean & 23.48 & 20.66 & 17.70 & 20.61 \\
\hline \multirow{3}{*}{ HA } & Micro-PPPb & 24.10 & 22.60 & 19.10 & 21.93 \\
\hline & Non-PPPb & 24.22 & 22.94 & 20.30 & 22.49 \\
\hline & Mean & 24.16 & 22.77 & 19.70 & 22.21 \\
\hline \multirow{3}{*}{ EM } & Micro-PPPb & 23.80 & 21.35 & 18.90 & 21.35 \\
\hline & Non-PPPb & 23.95 & 22.46 & 20.00 & 22.14 \\
\hline & Mean & 23.88 & 21.91 & 19.45 & 21.74 \\
\hline \multirow{3}{*}{ SWE+HA } & Micro-PPPb & 24.55 & 22.62 & 20.00 & 22.39 \\
\hline & Non-PPPb & 24.70 & 23.48 & 21.35 & 23.18 \\
\hline & Mean & 24.63 & 23.05 & 20.68 & 22.78 \\
\hline \multirow{3}{*}{ SWE+EM } & Micro-PPPb & 24.20 & 21.82 & 19.32 & 21.78 \\
\hline & Non-PPPb & 24.36 & 22.70 & 20.64 & 22.57 \\
\hline & Mean & 24.28 & 22.26 & 19.98 & 22.17 \\
\hline \multirow{3}{*}{ HA+EM } & Micro-PPPb & 25.80 & 23.92 & 22.00 & 23.91 \\
\hline & Non-PPPb & 25.90 & 24.77 & 23.60 & 24.76 \\
\hline & Mean & 25.85 & 24.35 & 22.80 & 24.33 \\
\hline \multirow{3}{*}{ SWE+HA+EM } & Micro-PPPb & 27.40 & 25.78 & 24.00 & 25.73 \\
\hline & Non-PPPb & 27.50 & 26.47 & 25.30 & 26.42 \\
\hline & Mean & 27.45 & 26.13 & 24.65 & 26.08 \\
\hline \multirow{2}{*}{ Mean } & Micro-PPPb & 24.40 & 22.14 & 19.48 & 22.01 \\
\hline & Non-PPPb & 24.54 & 22.84 & 20.71 & 22.70 \\
\hline Mean & Mean & 24.47 & 22.49 & 20.10 & \\
\hline \multicolumn{6}{|l|}{ LSD at $5 \%$} \\
\hline Treatment $(\mathbf{T})$ & & 0.97 & $\mathbf{T} \times \mathbf{P}$ & 1.37 & \\
\hline Packaging (P) & & 0.48 & $\mathbf{T} \times \mathbf{S}$ & 1.68 & \\
\hline \multirow[t]{2}{*}{ Storage period $(S)$} & & 0.59 & $\mathbf{P} \times \mathbf{S}$ & 0.84 & \\
\hline & & & $\mathbf{T} \times \mathbf{P} \times \mathbf{S}$ & 2.37 & \\
\hline
\end{tabular}

\footnotetext{
${ }^{\mathrm{x}}$ SWE: Seaweed extract, HA: Humic acid, EM: Effective microorganisms.
}

y Micro-PPPb: Micro-perforated polypropylene bags.

Non-PPPb: Non-perforated polypropylene bags. 
Table 6. Effect of some bio-stimulants and packaging material on total carbohydrates (\%) of snap beans during storage at $5^{\circ} \mathrm{C}$, with additional 2 days at $10^{\circ} \mathrm{C}$ in $2015 / 2016$ season.

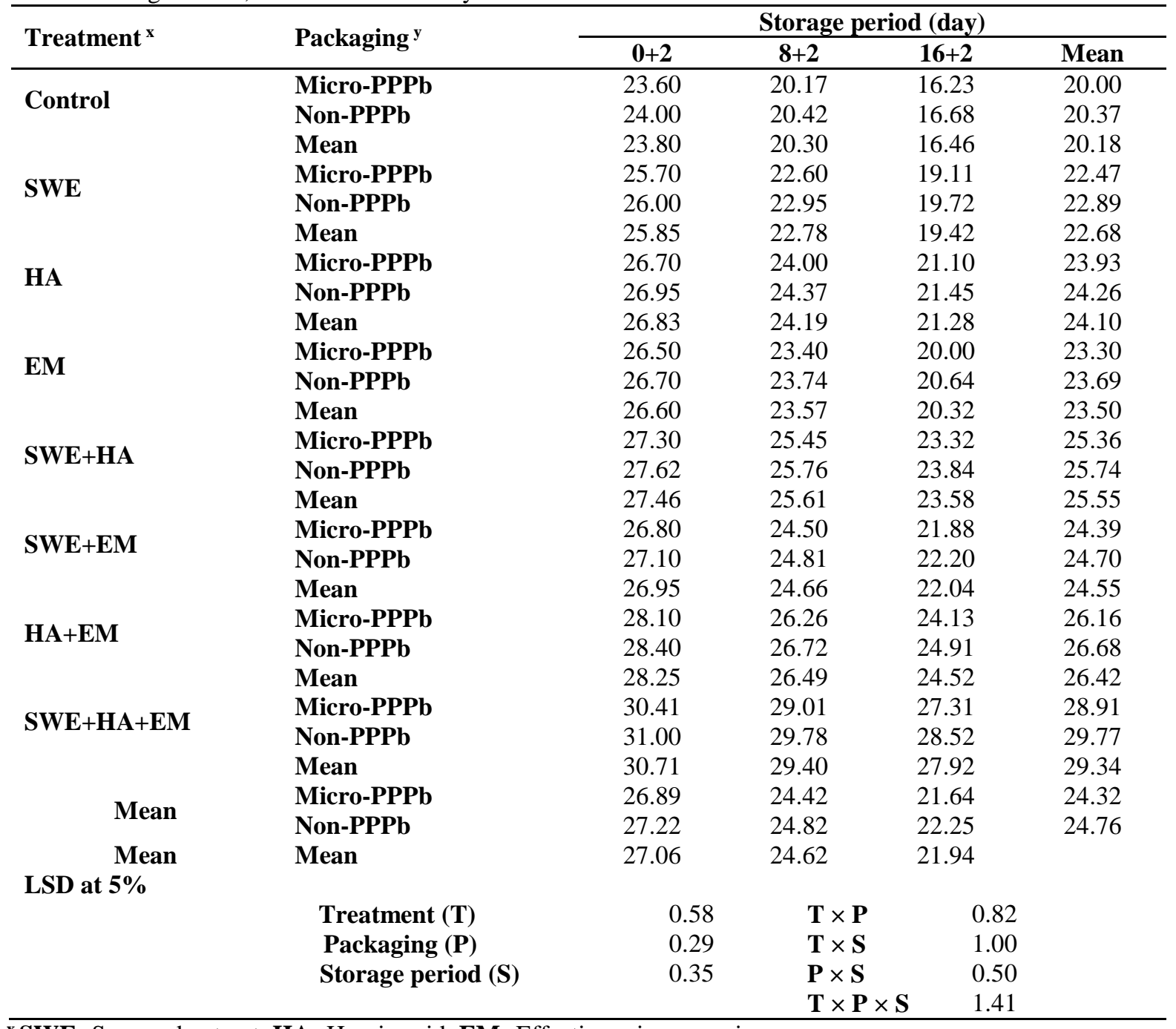

xWE: Seaweed extract, HA: Humic acid, EM: Effective microorganisms.

${ }^{\mathbf{y}}$ Micro-PPPb: Micro-perforated polypropylene bags.

Non-PPPb: Non-perforated polypropylene bags.

In general, the interaction among pre-harvest treatments, packaging material and storage periods plus shelf life was significant in both seasons, after 16 days at $5^{\circ} \mathrm{C}+2$ days at $10^{\circ} \mathrm{C}$ of storage, snap bean pods obtained from plants treated with the mixture of SWE + HA + EM and then packed in non$\mathrm{PPPb}$ or micro-PPPb maintained total carbohydrates $\%$ without significant differences between them in the two seasons.

\section{Protein percentage}

Data in Tables $7 \& 8$ reveal that protein \% of snap bean pods decreased with the prolongation of storage period and shelf life; these results were achieved in the two seasons and are in agreement with those obtained by El-Sayed et al. (2015) on snap bean.

Snap bean pods obtained from plants treated with all pre-harvest treatments had significantly highest protein $\%$ as compared with pods obtained from untreated plants during storage and shelf life.
However, snap bean pods obtained from plants treated with the mixture of SWE + HA + EM or HA + EM were the most effective treatments in maintaining protein $\%$ of pods with significant differences between them in the two seasons, while the lowest values of protein $\%$ were recorded for pods obtained from the untreated plants. These results were achieved in the two seasons and are in agreement with those obtained by Mohamed (2014) for SWE and HA on pea and El-Sayed et al. (2015) for HA and EM on snap bean. The enhancement effect of SWE application on pod protein \% may be due to its important role in the biosynthesis of chlorophyll molecules which in turn affected total carbohydrates content by increasing photosynthetic translocation from source to sink and increasing of different growth substances (Zewail, 2014) and then maintained protein content during storage (Mohamed, 2014). Also, HA application increased leaf $\mathrm{N}$ content which is a precursor of amino acids and in turn 
reflected a synergistic effect in protein synthesis (Tantawy et al., 2009) and also maintained protein content during storage (El-Sayed et al., 2015). EM contains bacteria and yeast which via its content of cytokinin might play a role in the synthesis of protein and nucleic acids and minimized their degradation (Legocka, 1987) and maintained protein content during storage (El-Sayed et al., 2015).

Concerning the effect of packaging material, data reveal that snap bean pods packed in non-PPPb had the highest values of protein $\%$, while those packed in micro-PPPb had the lowest ones. These results were achieved in the two seasons and are in agreement with those obtained by El-Bassiouny (2003) on snap bean pods.

The interaction between pre-harvest treatments and packaging material was significant in the two seasons, data show that snap bean pods obtained from plants treated with the mixture of SWE + HA + $\mathrm{EM}$ and then packed in non-PPPb or micro-PPPb had the highest values of protein $\%$ without significant differences between them in the two seasons. The lowest ones were found in those obtained from the untreated plants and then packed in micro-PPPb or non- $\mathrm{PPPb}$ without significant differences between them in the two seasons.

Concerning the interaction among pre-harvest treatments, packaging material and storage periods plus shelf life, the results reveal that snap bean pods obtained from plants treated with the mixture of $\mathrm{SWE}+\mathrm{HA}+\mathrm{EM}$ and then packed in non-PPPb or micro-PPPb had the highest values of total protein $\%$ without significant differences between them in all storage periods and shelf life in the two seasons, while the lowest ones were found in those obtained from untreated plants and then packed in micro- $\mathrm{PPPb}$ or non-PPPb without significant differences between them in all storage periods plus shelf life in the two seasons.

Table 7. Effect of some bio-stimulants and packaging material on protein (\%) of snap beans during storage at $5^{\circ} \mathrm{C}$, with additional 2 days at $10^{\circ} \mathrm{C}$ in $2014 / 2015$ season.

\begin{tabular}{|c|c|c|c|c|c|}
\hline \multirow{2}{*}{ Treatment $^{\mathrm{x}}$} & \multirow{2}{*}{ Packaging ${ }^{\mathrm{y}}$} & \multicolumn{4}{|c|}{ Storage period (day) } \\
\hline & & $0+2$ & $8+2$ & $16+2$ & Mean \\
\hline \multirow{3}{*}{ Control } & Micro-PPPb & 15.28 & 12.38 & 9.20 & 12.29 \\
\hline & Non-PPPb & 15.60 & 13.00 & 10.10 & 12.90 \\
\hline & Mean & 15.44 & 12.69 & 9.65 & 12.59 \\
\hline \multirow{3}{*}{ SWE } & Micro-PPPb & 16.62 & 14.12 & 11.50 & 14.08 \\
\hline & Non-PPPb & 16.90 & 14.66 & 12.30 & 14.62 \\
\hline & Mean & 16.76 & 14.39 & 11.90 & 14.35 \\
\hline \multirow{3}{*}{ HA } & Micro-PPPb & 18.00 & 15.70 & 13.35 & 15.68 \\
\hline & Non-PPPb & 18.25 & 16.16 & 14.05 & 16.15 \\
\hline & Mean & 18.13 & 15.93 & 13.70 & 15.92 \\
\hline \multirow{3}{*}{ EM } & Micro-PPPb & 17.20 & 14.80 & 12.30 & 14.77 \\
\hline & Non-PPPb & 17.52 & 15.32 & 13.00 & 15.28 \\
\hline & Mean & 17.36 & 15.06 & 12.65 & 15.02 \\
\hline \multirow{3}{*}{ SWE+HA } & Micro-PPPb & 18.30 & 16.20 & 14.00 & 16.17 \\
\hline & Non-PPPb & 18.54 & 16.68 & 14.65 & 16.62 \\
\hline & Mean & 18.42 & 16.44 & 14.33 & 16.40 \\
\hline \multirow{3}{*}{ SWE+EM } & Micro-PPPb & 18.00 & 15.72 & 13.40 & 15.71 \\
\hline & Non-PPPb & 18.20 & 16.20 & 14.13 & 16.18 \\
\hline & Mean & 18.10 & 15.96 & 13.77 & 15.94 \\
\hline \multirow{3}{*}{ HA+EM } & Micro-PPPb & 18.90 & 17.21 & 15.50 & 17.20 \\
\hline & Non-PPPb & 19.10 & 17.62 & 16.10 & 17.61 \\
\hline & Mean & 19.00 & 17.42 & 15.80 & 17.41 \\
\hline \multirow{3}{*}{ SWE+HA+EM } & Micro-PPPb & 20.50 & 18.77 & 17.00 & 18.76 \\
\hline & Non-PPPb & 20.73 & 19.23 & 17.60 & 19.19 \\
\hline & Mean & 20.62 & 19.00 & 17.30 & 18.97 \\
\hline \multirow{2}{*}{ Mean } & Micro-PPPb & 17.85 & 15.61 & 13.28 & 15.58 \\
\hline & Non-PPPb & 18.11 & 16.11 & 13.99 & 16.07 \\
\hline Mean & Mean & 17.98 & 15.86 & 13.64 & \\
\hline \multicolumn{6}{|l|}{ LSD at $5 \%$} \\
\hline & Treatment (T) & 0.66 & & & \\
\hline & Packaging (P) & 0.33 & & & \\
\hline & Storage period $(\mathbf{S})$ & 0.41 & & & \\
\hline & & & & & \\
\hline
\end{tabular}

xSWE: Seaweed extract, HA: Humic acid, EM: Effective microorganisms.

y Micro-PPPb: Micro-perforated polypropylene bags.

Non-PPPb: Non-perforated polypropylene bags. 
Table 8. Effect of some bio-stimulants and packaging material on protein (\%) of snap beans during storage at $5^{\circ} \mathrm{C}$, with additional 2 days at $10^{\circ} \mathrm{C}$ in $2015 / 2016$ season.

\begin{tabular}{|c|c|c|c|c|c|}
\hline \multirow{2}{*}{ Treatment $^{\mathrm{x}}$} & \multirow{2}{*}{ Packaging ${ }^{\mathrm{y}}$} & \multicolumn{4}{|c|}{ Storage period (day) } \\
\hline & & $0+2$ & $8+2$ & $16+2$ & Mean \\
\hline \multirow{3}{*}{ Control } & Micro-PPPb & 16.50 & 13.32 & 10.10 & 13.31 \\
\hline & Non-PPPb & 16.80 & 13.64 & 10.40 & 13.61 \\
\hline & Mean & 16.65 & 13.48 & 10.25 & 13.46 \\
\hline \multirow{3}{*}{ SWE } & Micro-PPPb & 18.00 & 15.22 & 12.42 & 15.21 \\
\hline & Non-PPPb & 18.30 & 15.60 & 12.80 & 15.57 \\
\hline & Mean & 18.15 & 15.41 & 12.61 & 15.39 \\
\hline \multirow{3}{*}{ HA } & Micro-PPPb & 18.70 & 15.81 & 13.00 & 15.84 \\
\hline & Non-PPPb & 19.10 & 16.27 & 13.42 & 16.26 \\
\hline & Mean & 18.90 & 16.04 & 13.21 & 16.05 \\
\hline \multirow{3}{*}{ EM } & Micro-PPPb & 18.40 & 15.41 & 12.70 & 15.50 \\
\hline & Non-PPPb & 18.70 & 15.90 & 13.10 & 15.90 \\
\hline & Mean & 18.55 & 15.66 & 12.90 & 15.70 \\
\hline \multirow{3}{*}{ SWE+HA } & Micro-PPPb & 19.20 & 16.81 & 14.40 & 16.80 \\
\hline & Non-PPPb & 19.50 & 17.21 & 14.90 & 17.20 \\
\hline & Mean & 19.35 & 17.01 & 14.65 & 17.00 \\
\hline \multirow{3}{*}{ SWE+EM } & Micro-PPPb & 19.00 & 16.61 & 14.20 & 16.60 \\
\hline & Non-PPPb & 19.20 & 16.98 & 14.70 & 16.96 \\
\hline & Mean & 19.10 & 16.80 & 14.45 & 16.78 \\
\hline \multirow{3}{*}{ HA+EM } & Micro-PPPb & 20.10 & 18.20 & 15.90 & 18.07 \\
\hline & Non-PPPb & 20.50 & 18.56 & 16.60 & 18.55 \\
\hline & Mean & 20.30 & 18.38 & 16.25 & 18.31 \\
\hline \multirow{3}{*}{ SWE+HA+EM } & Micro-PPPb & 21.60 & 19.93 & 18.23 & 19.92 \\
\hline & Non-PPPb & 22.00 & 20.48 & 18.94 & 20.47 \\
\hline & Mean & 21.80 & 20.21 & 18.59 & 20.20 \\
\hline \multirow{2}{*}{ Mean } & Micro-PPPb & 18.94 & 16.41 & 13.87 & 16.41 \\
\hline & Non-PPPb & 19.26 & 16.83 & 14.36 & 16.82 \\
\hline Mean & Mean & 19.10 & 16.62 & 14.11 & \\
\hline \multicolumn{6}{|l|}{ LSD at $5 \%$} \\
\hline & Packaging (P) & 0.26 & $\mathbf{T} \times \mathbf{S}$ & 0.91 & \\
\hline & Storage period (S) & 0.32 & $P \times S$ & 0.45 & \\
\hline & & & $\mathbf{T} \times \mathbf{P} \times \mathbf{S}$ & 1.28 & \\
\hline
\end{tabular}

${ }^{\mathrm{x} S W E}$ : Seaweed extract, HA: Humic acid, EM: Effective microorganisms.

${ }^{y}$ Micro-PPPb: Micro-perforated polypropylene bags.

Non-PPPb: Non-perforated polypropylene bags.

\section{Fiber percentage}

Data in Tables $9 \& 10$ reveal that fiber $\%$ of snap bean pods increased with the prolongation of storage period plus shelf life, these results were achieved in the two seasons and are in agreement with those obtained by El-Mogy (2001) on snap beans. The increase in fiber during storage may be due to moisture loss during storage (El-Sheikh and Salah, 1998).

All pre-harvest treatments had significantly lower fiber percentages as compared with untreated plants, except SWE treatment alone in the first season. Snap bean pods obtained from plants treated with the mixture of SWE + HA + EM or HA + EM gave the minimum values of fiber $\%$ during storage and shelf life with significant differences between them in the two seasons, while the highest ones were obtained from untreated control in the two seasons. These results are in agreement with those obtained by Mohamed (2014) for SWE or HA on pea. The effect of HA on decreasing fiber content may be due to that HA enhanced uptake of macronutrients and important action of humic substances on plant nutrient acquisition and in the uptake of nutrients such as nitrogen, phosphorus and sulfur (Chen and Avied, 1990), increasing plant growth promoters (Kaya et al., 2005) which reduce fiber content in the pods (El-Bassiony et al., 2010), and subsequently decrease fiber content during storage (Mohamed, 2014).

Significant differences in fiber $\%$ of snap bean pods were found between micro-PPPb and non- $\mathrm{PPPb}$ during storage and shelf life. Snap bean pods packed in non-PPPb had the lowest value of fiber \%, while the highest ones were obtained from pods packed in micro-perforated ones. These results were achieved in the two seasons and are in agreement with those obtained by El-Sheikh (1979) on snap bean.

The interaction between pre-harvest treatments and packaging material was significant in the two 
seasons. Snap bean pods obtained from plants treated with the mixture of SWE + HA + EM and then packed in non-PPPb or micro-PPPb had the lowest values of fiber percentage without significant differences between them in the two seasons, while the highest ones were found in those obtained from untreated plants and then packed in micro-PPPb in the two seasons.

In general, the interaction among pre-harvest treatments, packaging material and storage periods plus shelf life was significant in both seasons. After 16 days of storage at $5^{\circ} \mathrm{C}+2$ days at $10^{\circ} \mathrm{C}$, snap bean pods obtained from plants treated with the mixture of $\mathrm{SWE}+\mathrm{HA}+\mathrm{EM}$ and then packed in non-PPPb or micro-PPPb had the lowest values of fiber percentage without significant differences between them in the second season, while pods obtained from plants treated with SWE or EM and untreated plants and then packed in micro-PPPb or non-PPPb had the highest ones without significant differences between them in the second season.

\section{Conclusion}

From the previous results, it could be concluded that treating snap bean pants with a mixture of SWE $+\mathrm{HA}+\mathrm{EM}$ and then packing in non-perforated polypropylene bags improved storability, maintained pod quality attributes, and gave good appearance of pods after 16 days of storage at $5^{\circ} \mathrm{C}+2$ days at $10^{\circ} \mathrm{C}$ (shelf life).

Table 9. Effect of some bio-stimulants and packaging material on fiber (\%) of snap beans during storage at $5^{\circ} \mathrm{C}$, with additional 2 days at $10^{\circ} \mathrm{C}$ in $2014 / 2015$ season.

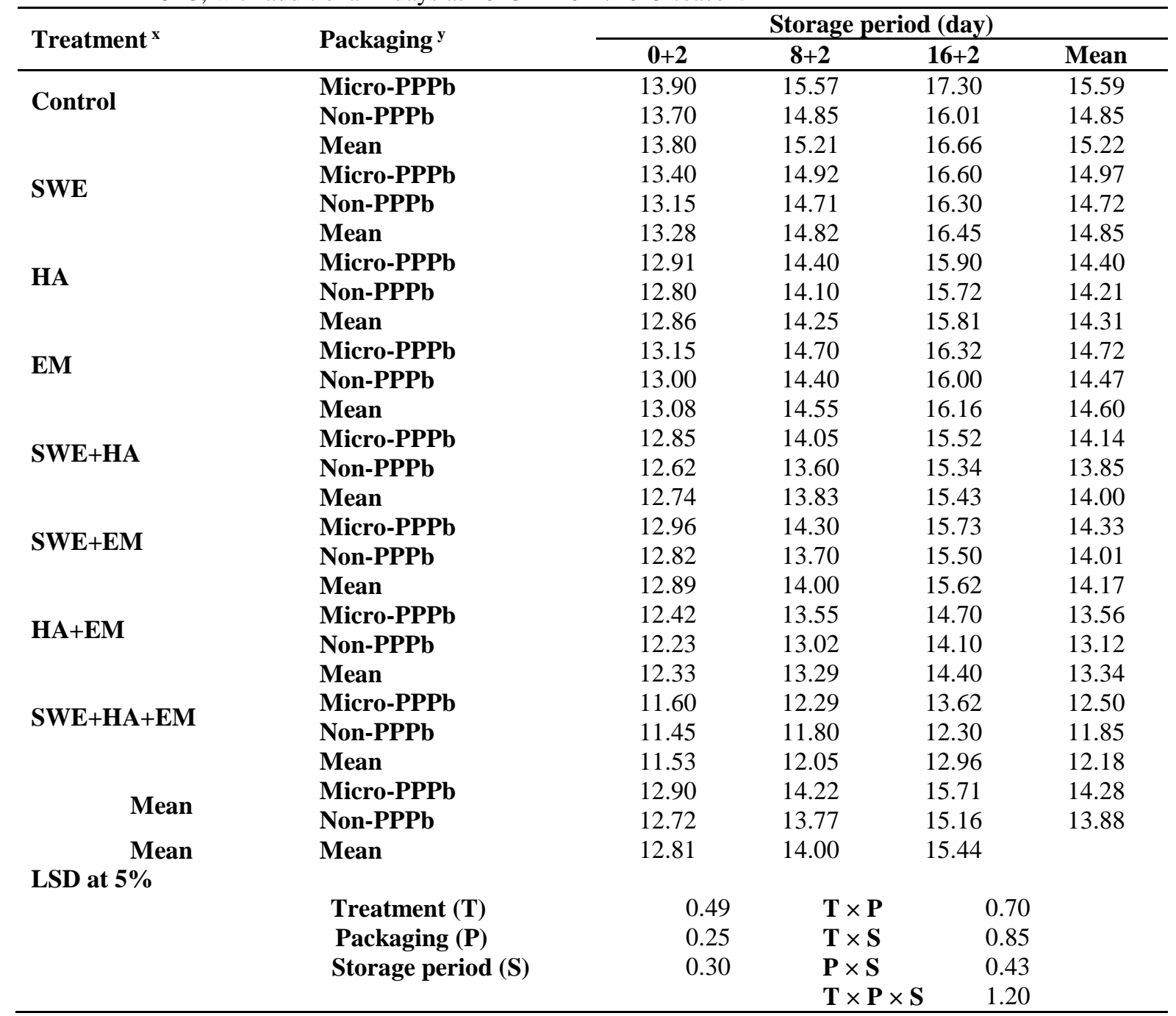

\footnotetext{
${ }^{x}$ SWE: Seaweed extract, HA: Humic acid, EM: Effective microorganisms.
}

${ }^{\mathbf{y}}$ Micro-PPPb: Micro-perforated polypropylene bags.

Non-PPPb: Non-perforated polypropylene bags. 
Table 10. Effect of some bio-stimulants and packaging material on fiber (\%) of snap beans during storage at $5^{\circ} \mathrm{C}$, with additional 2 days at $10^{\circ} \mathrm{C}$ in $2015 / 2016$ season.

\begin{tabular}{|c|c|c|c|c|c|}
\hline \multirow{2}{*}{ Treatment $^{x}$} & \multirow{2}{*}{ Packaging ${ }^{\mathrm{y}}$} & \multicolumn{4}{|c|}{ Storage period (day) } \\
\hline & & $0+2$ & $8+2$ & $16+2$ & Mean \\
\hline \multirow{3}{*}{ Control } & Micro-PPPb & 12.84 & 14.33 & 15.82 & 14.33 \\
\hline & Non-PPPb & 12.67 & 14.07 & 15.50 & 14.08 \\
\hline & Mean & 12.76 & 14.20 & 15.66 & 14.21 \\
\hline \multirow{3}{*}{ SWE } & Micro-PPPb & 12.30 & 13.85 & 15.42 & 13.86 \\
\hline & Non-PPPb & 12.20 & 13.61 & 15.11 & 13.64 \\
\hline & Mean & 12.25 & 13.73 & 15.27 & 13.75 \\
\hline \multirow{3}{*}{ HA } & Micro-PPPb & 12.00 & 13.40 & 14.82 & 13.41 \\
\hline & Non-PPPb & 11.90 & 13.10 & 14.50 & 13.17 \\
\hline & Mean & 11.95 & 13.25 & 14.66 & 13.29 \\
\hline \multirow{3}{*}{ EM } & Micro-PPPb & 12.20 & 13.64 & 15.10 & 13.65 \\
\hline & Non-PPPb & 12.10 & 13.50 & 15.00 & 13.53 \\
\hline & Mean & 12.15 & 13.57 & 15.05 & 13.59 \\
\hline \multirow{3}{*}{ SWE+HA } & Micro-PPPb & 11.86 & 13.11 & 14.40 & 13.12 \\
\hline & Non-PPPb & 11.74 & 12.91 & 14.10 & 12.92 \\
\hline & Mean & 11.80 & 13.01 & 14.25 & 13.02 \\
\hline \multirow{3}{*}{ SWE+EM } & Micro-PPPb & 11.92 & 13.25 & 14.62 & 13.26 \\
\hline & Non-PPPb & 11.81 & 13.00 & 14.20 & 13.00 \\
\hline & Mean & 11.87 & 13.13 & 14.41 & 13.13 \\
\hline \multirow{3}{*}{ HA+EM } & Micro-PPPb & 11.35 & 12.38 & 13.43 & 12.39 \\
\hline & Non-PPPb & 11.17 & 12.10 & 13.20 & 12.16 \\
\hline & Mean & 11.26 & 12.24 & 13.32 & 12.27 \\
\hline \multirow{3}{*}{ SWE+HA+EM } & Micro-PPPb & 10.43 & 11.40 & 12.43 & 11.42 \\
\hline & Non-PPPb & 10.30 & 11.10 & 12.00 & 11.13 \\
\hline & Mean & 10.37 & 11.25 & 12.22 & 11.28 \\
\hline \multirow{2}{*}{ Mean } & Micro-PPPb & 11.86 & 13.17 & 14.51 & 13.18 \\
\hline & Non-PPPb & 11.74 & 12.92 & 14.20 & 12.95 \\
\hline & Mean & 11.80 & 13.05 & 14.35 & \\
\hline \multicolumn{6}{|l|}{ LSD at $5 \%$} \\
\hline & Treatment $(\mathbf{T})$ & 0.45 & $\mathbf{T} \times \mathbf{P}$ & 0.65 & \\
\hline & Packaging (P) & 0.22 & $\mathbf{T} \times \mathbf{S}$ & 0.79 & \\
\hline & Storage period (S) & 0.28 & $\mathbf{P} \times \mathbf{S}$ & 0.40 & \\
\hline & & & $\mathbf{T} \times \mathbf{P} \times \mathbf{S}$ & 1.12 & \\
\hline
\end{tabular}

${ }^{\mathrm{x}}$ SWE: Seaweed extract, HA: Humic acid, EM: Effective microorganisms

${ }^{y}$ Micro-PPPb: Micro-perforated polypropylene bags.

Non-PPPb: Non-perforated polypropylene bags.

\section{References}

Abou El-Yazied, A.; El-Gizawy, A.M.; Ragab, M.I. and Hamed, E.S. (2012). Effect of seaweed extract and compost treatments on growth, yield and quality of snap bean. J. of American Sci., $8(6): 1-20$.

AOAC. (1990). Quality of Official Analytical Chemists, Washington DC. USA.

Chen, Y. and Aviad, T. (1990). Effect of humic substances on plant growth. Humic substances in soil and crop science: Selected readings humicsubstances, pp. 161-186.

Crouch, I.J. and Van-Staden, J. (1993). Evidence for the presence of plant growth regulators in commercial seaweed products. J. Plant Growth Regul., 13:21-29.

Dubois, M.; Gilles, R.A.; Hamillon, J.; Rebers, R. and Smith, I. (1956). Colorimertic method for determination of sugars and related substances. Anal. Chem., 28:350-356.
El-Bassiony, A.M.; Fawzy, Z.F.; Abd El-Baky, M.M.H. and Mahmoud A.R. (2010). Response of snap bean plants to mineral fertilizers and humic acid application. Research Journal of Agriculture and Biological Sciences, 6(2):169175.

El-Bassiouny, R.E.I. (2003). Modified atmosphere polyethylene packages maintain the quality of snap bean pods during storage. J. Agric. Sci., Mansoura Univ., 28(5):3869-3891.

El-Mogy, M.M. (2001). Effect of some pre and Postharvest Treatments on Storability of some Snap Bean Cultivars. M.Sc. Thesis, Fac. Agric., Cairo Univ., Egypt, 101 p.

El-Sayed, H.A.; Zaghloul, M.M.; Nour, K.A.M. and Attia, R.H. (2015). Treatment of snap bean plants grown under sandy soil conditions with some natural materials and its relation to growth, yield and pod quality. J. plant production, Mansoura Univ., 6(3): 395-421. 
El-Sheikh, T.M. and Salah, M.M. (1998). Studies on improving productivity, quality and storage ability of snap bean under protected cultivation. J. Agric. Sci., Mansoura Univ., 23(4):1671-1688.

El-Sheikh, T.M.A. (1979). Physiological Studies on the Handling of Beans and Cucumber. M.Sc. Thesis, Fac., Agric., Zagazig Univ., Cairo, Egypt, $129 \mathrm{p}$.

Fallik, E.; Chalupowicz, D.; Aharon, Z. and Aharoni, N. (2002). Modified atmosphere in a water vapour-permeable film maintains snap bean quality after harvest. Folia Horticulturae, 14(2):85-94.

Gad El-Hak, S.H.; Ahmed, A.M. and Moustafa, Y.M.M. (2012). Effect of foliar application with two antioxidants and humic acid on growth, yield and yield components of peas (Pisum sativum L.). Journal of Horticultural Science \& Ornamental Plants, 4 (3):318-328.

Hammam, Kh.A. (2016). Effect of post-harvest treatments on parsley (Petroselinum crispum, L.) fresh herb grown under organic cultivation condition. Egypt J. of Appl. Sci., 31(1):23-46.

Higa, T. and Wididana, G.N. (1991). Changes in the soil microflora induced by effective microorganism. Proceedings of the First International Conference on Kyusei Nature Farming. US Department of Agriculture, Washington, DC, USA, pp.153-162.

Kader, A.A.; Morris, L.L. and Maxie, E.C. (1973). Systems for scoring quality of harvested lettuce. Hort. Sci., 8: 408-409.

Kaya, M.; Atak, M.; Khawar, K.M.; Çiftçi, C.Y. and Özcan, S. (2005). Effect of pre-sowing seed treatment with zinc and foliar spray of humic acid on yield of common bean (Phaseolus vulgaris L.). International Journal of Agriculture \& Biology, 6:875-878.

Kerlous, A.N.K. (1997). Effect of sowing dates and water stress on productivity of bean (Phaseolus vulgaris L.) plants. M. Sc. Thesis, Fac. Agric., Ain Shams Univ., Cairo, Egypt.

Khan, W.; Rayirath, U.P.; Subramanian, S.; Jithesh, M.N.; Rayorath, P.; Hodges, D.M.; Critchley, A.T.; Craigie, J. S.; Norrie, J. and Prithiviraj, B. (2009) Seaweed extracts as biostimulants of plant growth and development. J. Plant Growth Regul., 28:386-399.

Legocka, J. (1987). Kinetin induced changes in the population of translatable messenger RNA lacking a polyactenylated segment in cucumber cotyledons. Acta Physiol. Plant, 9(1):33-39.

Lucera, A.; Conte, A. and Del Nobile, M.A. (2011). Shelf life of fresh-cut green beans as affected by packaging systems. Int. J. Food Sci. \& Technol., 46(11):2351-2357.

Mikkelsen, R.L. (2005). Humic materials for agriculture. Better Crops, 89(3):6-10.

Mohamed, O.O. (2014). Impact of preharvest foliar spray with some safety substances on yield and storability of fresh cut green pea seeds (Pisum sativum L.) during storage. Zagazig J. Agric. Res., 41(6)1:18.

Rai, S.N. and Mudgal, V.D. (1988). Synergistic effect of sodium hydroxide and steam pressure treatment on compositional changes and fibre utilization of wheat straw. Biological waster, 24:105- 114.

Sames, C.E. (1999). Preharvest factors affecting postharvest texture. Postharvest Biol. Technol., 15(3):249-254.

Senn, T.L. (1991). Humates in Agriculture. Acres USA, Jan.

Shehata, S.A.; Said, Z.A.; Attia, M.M. and Rageh, M.A. (2015). Effect of foliar application of micronutrients, magnesium and wrapping films on yield, quality and storability of green bean pods. Fayoum J. Agric. Res. \& Dev., 30(1):121139.

Snedecor, G.W. and Cochran, W.G. (1980). Statistical Methods. $8^{\text {th }}$ Ed., Iowa State Univ. Press, Ames, Iowa, USA. 476 p.

Tantawy, A.S.; Abd El-Mawgoud, A.M.R.; Habib, H.A.M. and Hafez, M.M. (2009). Growth, productivity and pod quality responses of green bean plants to foliar application of nutrients and pollen extracts. Res. J. Agric. Biolo. Sci., 5(6): 1032- 1038.

Thompson, A.K. (1996). Post-harvest technology of fruits and vegetables, Cambridge, Mass: Blackwell Sci., No. 634.

Wang, C.Y. and Qi, L. (1997). Modified atmosphere package alleviates chilling injury in cucumbers. Postharvest Biol. and Technol., 10:195-200

Wills, R.; Mcglasson, B.; Graham, D. and Joyce, D. (1998). Post-harvest: An Introduction to the Physiology and Handling of fruit, Vegetables and Ornamentals. Wallingford: CAB Inter., 262 pp.

Wills, R.B.H.; McGlasson, W.B.; Graham, D.; Lee, T.H. and Hall, E.G. (1989). Postharvest an introduction to the physiology and handling of fruit and vegetables. $3^{\text {rd }}$ edit. New York. Van Nostrand Reinhol.

Woodward, D. (2003). Soil and sustainability. Effective micro-organisms as regenerative systems in earth healing. http://www.livingsoil.co.uk/learning/soilsustain.h tm (Accessed 23/9/2008).

Youssef, K.T.; Mohamed, R.D. and Ahmed, R. (2010). Evaluation of locally made modified atmosphere packaging for Egyptian green beans. Journal of Food, Agriculture \& Environment, 8(2):280-283.

Zewail, R.M.Y. (2014). Effect of seaweed extract and amino acids on growth and productivity and some biocostituents of common bean (Phaseolus vulgaris, L.) plants. J. Plant Production, Mansoura Univ., 5(8):1441-1453. 
تأثير بعض المنشطات الحيوية ومواد التعبئة على صفات الجودة لقرون الفاصوليا الخضراء خلال التخزين وفترة العرض

سعيد عبدالله شحاتة'، سعيد زكريا عبد الرحمن²، مصطفى صالح إمام²، مصطفى عبد الفتاح الهلالى1، نوره على جاد الرب²

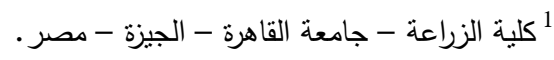

2 قسم بحوث تداول الخضر - معهد بحوث البساتين - الجيزة - مصر .

أجريت تجربتين تحت ظروف الصوب البلاستيكية خلال العروة الثنتى 2014 - 2015، و 2015 - 2016 فى تربة طينية طعيية

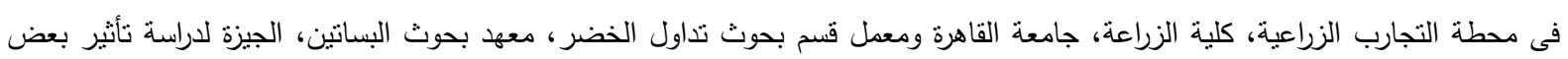

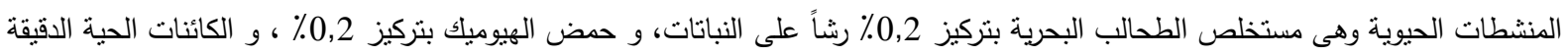

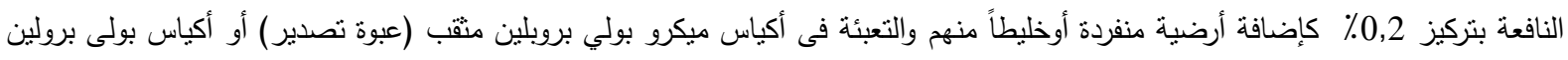

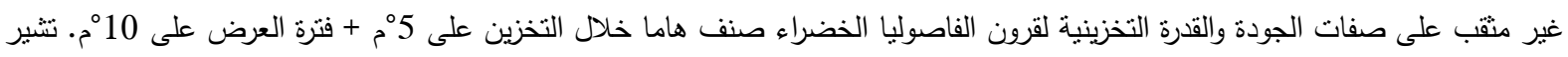

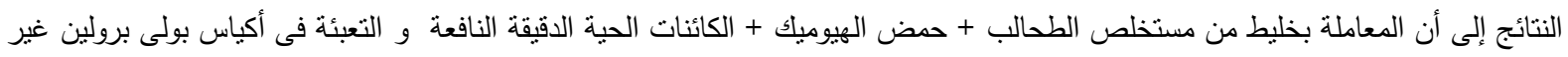

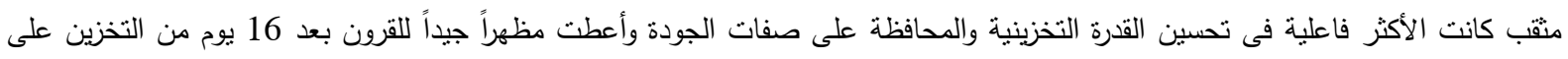
5ْم + 2 يوم على 10 مُ (فترة العرض).

الكلمات الدالة: الفاصوليا الخضراء، المنشطات الحيوية، الطحالب الخضراء، حمض الهيوميك، الكائنات الحية الدقيقة النافعة، التعبئة، أكياس مثقبة، أكياس غبر مثقبة، الجودة، القدرة التخزينية. 